\title{
Pontine tegmental cap dysplasia
}

A hindbrain malformation caused by defective neuronal migration

Figure Imaging features of pontine tegmental cap dysplasia
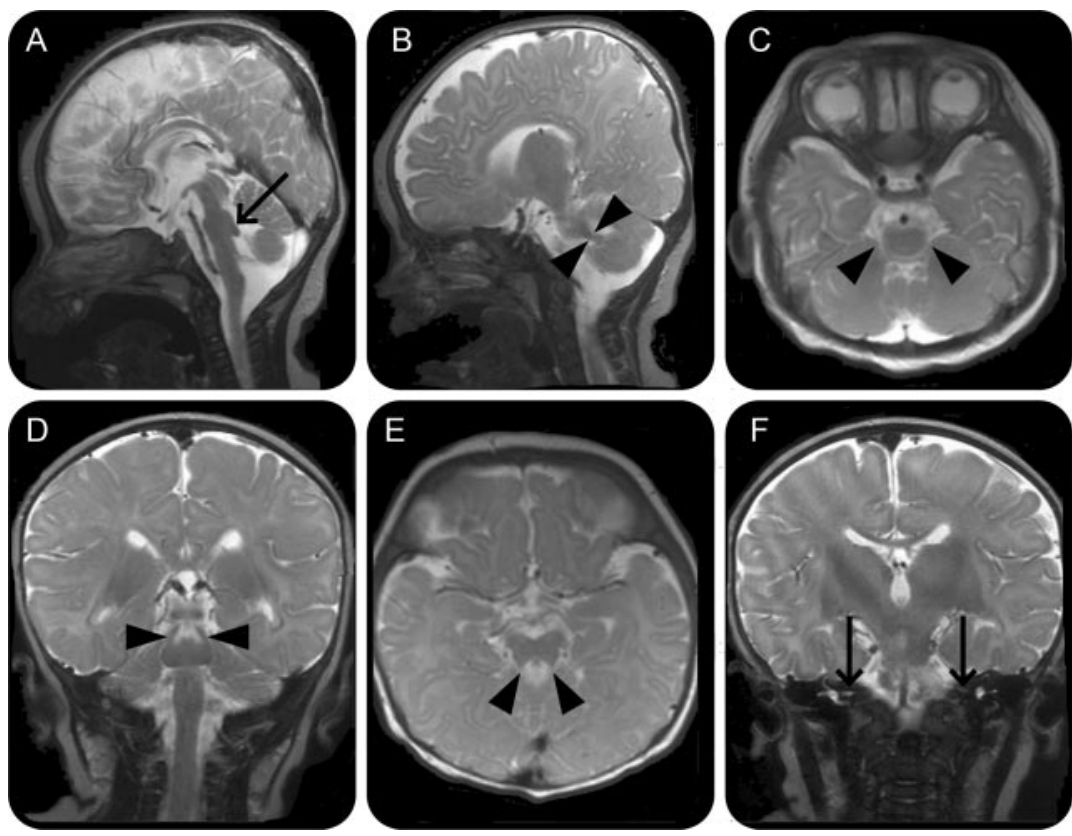

Fast spin echo/T2-weighted MRI showing flat ventral pons and a dorsal vault (arrow) projecting from the pontine tegmentum into the fourth ventricle (A); very thin (B) or not visible (C) middle cerebellar peduncles (arrowheads); abnormal shape and course of superior cerebellar peduncles (arrowheads) (D, E); very narrow internal auditory canals (arrows) (F).

A 13-month-old girl presented with developmental delay, generalized hypotonia, vertical pendular nystagmus, and cranial nerves IV, V, and VII paresis. MRI (figure) revealed pontine hypoplasia with ectopic dorsal transverse pontine fibers (tegmental cap). Concomitant profound sensorineural deafness and a butterfly $\mathrm{Th}_{2}$ vertebra led to the syndromic diagnosis of pontine tegmental cap dysplasia (PTCD).

PTCD has been described to date in several patients. ${ }^{1,2}$ It is suggested that many cases of pontocerebellar hypoplasia or Moebius syndrome should be revised for the features of PTCD. ${ }^{2}$ Pathomechanism of the condition involves defect in migration or navigation of axons of rhombencephalic neurons. ${ }^{1}$

K. Szczaluba, MD, PhD, K. Szymañska, MD, PhD, M. Bekiesińska-Figatowska, MD, PhD, E. Jurkiewicz, MD, PhD, J. Madzik, MD, PhD, E. Obersztyn, MD, PhD, T. Mazurczak, MD, PhD, Warsaw, Poland Disclosure: The authors report no disclosures.

Address correspondence and reprint requests to Dr. Krzysztof Szczaluba, Department of Medical Genetics, Institute of Mother and Child, Kasprzaka 17A St,01-211 Warsaw, Poland; kszczaluba@imid.med.pl

\section{ACKNOWLEDGMENT}

The authors thank Prof. Bwee Tien Poll-The for comments.

1. Barth PG, Majoie CB, Caan MWA, et al. Pontine tegmental cap dysplasia: a novel brain malformation with a defect in axonal guidance. Brain 2007;130:2258-2266.

2. Jissendi-Tchofo P, Doherty D, McGillivray G, et al. Pontine tegmental cap dysplasia: MR imaging and diffusion tensor imaging features of impaired axonal navigation. Am J Neuroradiol 2009;30:113-119. 


\section{Neurology}

\section{Pontine tegmental cap dysplasia: A hindbrain malformation caused by defective neuronal migration}

K. Szczaluba, K. Szymanska, M. Bekiesinska-Figatowska, et al. Neurology 2010;74;1835

DOI 10.1212/WNL.0b013e3181e0f7f8

\section{This information is current as of May 31, 2010}

\section{Updated Information \&} Services

References

Subspecialty Collections

Permissions \& Licensing

Reprints including high resolution figures, can be found at: http://n.neurology.org/content/74/22/1835.full

This article cites 2 articles, 1 of which you can access for free at: http://n.neurology.org/content/74/22/1835.full\#ref-list-1

This article, along with others on similar topics, appears in the following collection(s):

Developmental disorders

http://n.neurology.org/cgi/collection/developmental_disorders

Mental retardation

http://n.neurology.org/cgi/collection/mental_retardation

MRI

http://n.neurology.org/cgi/collection/mri

Ocular motility

http://n.neurology.org/cgi/collection/ocular_motility

Information about reproducing this article in parts (figures,tables) or in its entirety can be found online at:

http://www.neurology.org/about/about_the_journal\#permissions

Information about ordering reprints can be found online:

http://n.neurology.org/subscribers/advertise

Neurology ${ }^{\circledR}$ is the official journal of the American Academy of Neurology. Published continuously since 1951, it is now a weekly with 48 issues per year. Copyright . All rights reserved. Print ISSN: 0028-3878. Online ISSN: 1526-632X.

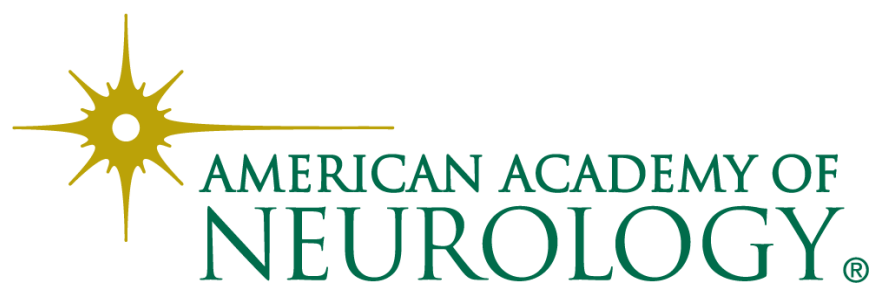

